\title{
P53 protein in proliferation, repair and apoptosis of cells
}

\author{
Ewelina Wawryk-Gawda • Patrycja Chylińska-Wrzos • Marta Lis-Sochocka • \\ Katarzyna Chłapek • Kamila Bulak • Marian Jędrych • Barbara Jodłowska-Jędrych
}

Received: 12 July 2013 / Accepted: 24 August 2013 / Published online: 17 September 2013

(C) The Author(s) 2013. This article is published with open access at Springerlink.com

\begin{abstract}
The $\mathrm{p} 53$ protein is an important factor of many intraand extracellular processes. This protein regulates the repair of cellular DNA and induces apoptosis. It is also responsible for the regulation of the senescence and the cell entering the subsequent stages of the cellular cycle. The protein p53 is also involved in inhibiting angiogenesis and the induction of oxidative shock. In our study, we examined the activity of p53 protein in the uterine epithelial cells in rats treated with cladribine. Its action is mainly based on apoptosis induction. We compared the activity of p53 protein in cells with a high apoptosis index and in cells with active repair mechanisms and high proliferation index. We observed stronger $\mathrm{p} 53$ protein expression in the epithelial cells of the materials taken $24 \mathrm{~h}$ after the last dose of 2-CdA associated with the active process of apoptosis and inhibition of proliferation. After 4 weeks from the last dose of cladribine, the stronger expression of p53 protein was associated with both the existing changes in the cell's genome, the effects of the ongoing repair mechanisms, as well as the high proliferation activity.
\end{abstract}

Keywords p53 protein $\cdot$ Proliferation $\cdot$ Apoptosis · Cladribine

Handling Editor: Jan Raoul De Mey

E. Wawryk-Gawda $(\bowtie) \cdot$ P. Chylińska-Wrzos $\cdot$ M. Lis-Sochocka

K. Bulak - B. Jodłowska-Jędrych

Department of Histology and Embryology with Experimental

Cytology Unit, Medical University in Lublin, ul. Radziwiłłowska 11, 20-080 Lublin, Poland

e-mail: ewelina.wawryk@wp.pl

K. Chłapek

Department of Financial Accounting,

Cracow University of Economics, Krakow, Poland

M. Jędrych

Department of Mathematics and Biostatistics, Medical University

of Lublin, ul. K. Jaczewskiego 4, 20-090 Lublin, Poland

\section{Introduction}

The p53 protein is a regulative factor of many processes necessary for the proper functioning of cells, and it corresponds to a number of processes associated with its life and death. The $\mathrm{p} 53$ protein regulates the repair of cellular DNA and induces apoptosis when the damage of the gene is too serious and it is impossible to repair. This protein is also responsible for the regulation of the senescence of cells and the cell entering and leaving the subsequent stages of the cellular cycle (in regard to the latter, the p53 protein can stop the cellular cycle in checkpoints $\mathrm{G} 1 / \mathrm{S}$ or $\mathrm{G} 2 / \mathrm{M}$ in order to run the repair mechanisms in the cell). What is more, the p53 protein can regulate intracellular processes directly or as result of interactions with other proteins found within the cell (Sznarkowska et al. 2010). It has also been demonstrated that the $\mathrm{p} 53$ protein, as a result of stress factors, crosses into the mitochondria and activates the expression of pro-apoptotic genes, such as Puma, Bax, Apaf-1, Noxa, as well as inhibits the expression of anti-apoptotic genes, such as those of the family Bcl-2 (Bcl-2, Bcl-X, Bcl-in, Mcl-1). These proapoptotic proteins, together with the $\mathrm{p} 53$ protein, are transported into the mitochondria where they induce an increase in the permeability of mitochondrial membranes and the release of cytochrome $c$, which connects with the Apoptotic protease activating factor 1 (Apaf-1) and with the caspase 9 proenzyme, to create the complex called the "apoptosome". The apoptosome, in turn, brings about caspase 9 activation, which consequently promotes the caspase 3 proenzyme to the active protease stage, which then adheres to the group of effector caspase. These caspases are responsible for intracellular protein lysis as well as for the morphological characteristic changes of apoptosis (Sznarkowska et al. 2010). What is more, the $\mathrm{p} 53$ protein participates in the regulation of the apoptosis pathway, albeit dependent upon the membranous death receptors, to regulate the height of the 
expression of gene coding receptors, such as FAS/APO1, DR5/KILLER, and also the development of the ligand of the FAS receptor (FasL). Furthermore, the promotion of the DR5 gene is indirectly activated by the p 53 protein. Instead, the expression of the FAS receptor on the cell's surface is enhanced by an increase in its transport from the Golgi apparatus to the cell membrane (Takimoto and El-Deiry 2000). The protein p53 is also involved in several other extracellular processes, among them, in inhibiting angiogenesis and the induction of oxidative shock. Under the right conditions, the protein p53 is kept in a cell at a low level and in an inactive form. During the course of the cell cycle, the level of this protein is closely controlled by a number of different factors, such as WT-1, MDM2, JNK, Pirh-2, PARP-1, and MDM4 protein (Pekova et al. 2011; Sznarkowska et al. 2010). However, in cells exposed to stress or exposed to factors damaging the DNA, the half-life of p53 active protein forms can be extended to several hours (Laptenko and Prives 2006), and according to some research, the active form of the protein $\mathrm{p} 53$ is also observed in proliferating cells (Borner et al. 1997; Mendoza-Rodríguez et al. 2002). In addition, in the last few years, a novel role for p53 in neurobiology has emerged. This includes a role in the regulation of neurite outgrowth and axonal regeneration. What is more, the p53 protein probably integrates a number of extracellular signals that involve neurotrophins and axon guidance cues to modulate the cytoskeletal response associated with neurite outgrowth at both the transcriptional and post-translational level (Di Giovanni and Rathore 2012).

In our study, we examined the activity of p53 protein in the epithelial cell of the uterine endometrium in female rats treated with cladribine (2-chlorodeoxyadenosine [2-CdA]). Cladribine represents a group of purine nucleoside analogues that belong to drugs used in chemotherapy of many malignances. Its action is mainly based on induction of apoptosis in cells on the intrinsic pathway, which has been shown in several studies (Klöpfer et al. 2004; Sznarkowska et al. 2010; Jedrych et al. 2013). The toxic effect of cladribine on the epithelial cells of the uterus is transient, as confirmed by analyzing the index proliferation of epithelial cells in different time since cessation of 2-CdA administration. In this study, we compared the activity of $\mathrm{p} 53$ protein in cells with a high index of apoptosis, and in cells with active repair mechanisms and high proliferation index.

\section{Materials and methods}

\section{Experimental model}

White female Wistar rats were used for the study. These were the 3- to 4-month-old females with an average body weight of $275 \mathrm{~g}$. Cladribine (Biodribin manufactured by the Institute of
Biotechnology and Antibiotics in Warsaw) was applied subcutaneously, interchangeably in the right and left side skin fold at the site of the lumbar spine (the study was approved by the Local Bioethics Commission of Medical University of Lublin - number 126/2001). During the experiment, the animals were housed in cages (one per cage) of a surface area of $0.5 \mathrm{~m}^{2}$, with a preserved circadian cycle $(12 \mathrm{~h}$ day, $12 \mathrm{~h}$ night), air temperature around $21{ }^{\circ} \mathrm{C}$ and relative humidity around $60 \%$. The rats received standard LSM feed and water without limitations. Before starting the experiment, a cytological smear of females was analyzed to determine the phase of the estrous cycle of the studied females. In all the studied females, the estrous cycle lasted 4 days and consisted of four phases: proestrus, estrus, metestrus, diestrus. On the first day of the fourth cycle, drug administration was begun.

\section{Research groups}

The animals were randomly placed into three groups: a control group (C) and two study groups (A and B), each of which consisted of five individuals. The animals in the study groups were given the drug at a dose of $0.10 \mathrm{mg} / \mathrm{kg} \mathrm{BW} / 24 \mathrm{~h}$, for 7 consecutive days, at exactly the same time. The dose employed corresponded to the therapeutic dose used in the treatment of proliferative disorders of the lymphatic system in humans. The control group animals received only food and water without limitations. In order to introduce a stressinducing factor as to that of the study groups, the rats in the control group were administered physiological saline subcutaneously in a volume corresponding to the amount of drug administered to rats in the study groups. Decapitation of animals of both group A and control group was conducted $24 \mathrm{~h}$ after the last injection, i.e., on the fourth day of the cycle (the final stage of diestrus). Decapitation of the animals in study group B was conducted 4 weeks after the last injection. Their uteruses were then taken for histomorphological and immunohistochemical tests.

\section{Histological tests}

\section{$H \& E$ staining}

After fixing the material in $10 \%$ buffered formalin, the organs were embedded in paraffin blocks. The material was then tailored into 5- $\mu \mathrm{m}$-thick sections. The histomorphological evaluation of tissues stained with hematoxylin and eosin (H\&E) was performed with the use of a light microscope using objective 20, 40 and 100. Mitotic activity of uterine epithelial cells we investigated by specifying cell mitotic index (MI). In so doing, we took ten fields of vision with objective 40, and analyzed 100 cells in each field of view. After this, we calculated the number of mitotic figures among the tested cells. The result was given as a percentage. 
Immunohistochemical tests

Immunohistochemical tests were then done using antibodies directed against protein 53 (P5813; Sigma-Aldrich, St. Louis, MO, USA; dilution 1:100), caspase 3 (WHO000836M2; Sigma-Aldrich; dilution 1:50), and Antigen Ki-67 (HPA 000451; Sigma-Aldrich; dilution 1:100). The exposure of the antigenic sites was performed thermally by incubation in citrate buffer solution with $\mathrm{pH}=6$, in a microwave oven at $800 \mathrm{~W}$, for 3 cycles lasting $5 \mathrm{~min}$ each. To inhibit endogenous peroxidase activity, $0.3 \%$ perhydrol $\left(\mathrm{H}_{2} \mathrm{O}_{2}\right)$ in methanol was used. Normal Serum was also used to block the nonspecific bindings of antigen. The material was incubated in a primary antibody diluted as recommended by the manufacturer overnight at $4{ }^{\circ} \mathrm{C}$. To visualize the reaction, diaminobenzidine solution (DAB) and hematoxylin colouration were used. In the negative control, experiments were conducted in a similar manner, but omitted the specific primary antibody. The material was evaluated with the use of a light microscope using objective $\times 20$ and $\times 40$. The percentage of cells with positive expression was calculated by counting approximated 300 cells in at least three randomly chosen microscopic fields (objective 40). Moreover, the intensity of expression of individual proteins of uterus epithelial cells was compared. The intensity was graded as low $(+)$, intermediate $(++)$ and high $(+++)$, by using the BX4 image analysis system manufactured by Olympus, with a DP 25 digital camera and the $C e 1 l^{\wedge} \mathrm{D}$ software. In addition, the percentage of cells of the given intensity expression in each analyzed fields was calculated. These values were expressed as a mean \pm standard deviation. The obtained tests results were subjected to statistical analysis with the use of Statistica 10.0 software StatSoft Polska. The chi-square $\left(\chi^{2}\right)$ test was applied to compare the mean of proteins indicating positive and negative cells in groups. Furthermore, a statistical analysis of the intensity of protein expression in groups was performed with the use of Kruskal-Wallis test. In this regard, a probability $(p)$ value less than 0.05 was considered statistically significant.

\section{Results}

Histomorphological assessment of the uterus epithelium in H\&E staining

The uterus epithelium of the tested groups of animals in the histomorphological study, showed no discernible pathological changes under the light microscope at $\times 40$ objective (Fig. 1), and the uterine cavity epithelium showed typical features for female rats in the diestrus phase. In addition, the single layer of columnar epithelium formed cells of low height, with oval centrally located nuclei. Moreover, the chromatin in the majority of cells represented heterochromatin. Furthermore, between the epithelial cells, single lymphocytes appeared, while in the uterine gland epithelium, quite a number of granulocytes were evident.

What is more, in individual cells, we observed mitotic divisions. These were visible in both the epithelial cell of the uterine endometrium and the cells of the uterine glands (Fig. 2). In ten fields of view under objective $\times 40$, the MI was calculated. The median amounted to $1.5 \%$ in the epithelial cells of the control group and the experimental B group of rats, while in the A experimental group epithelium, the median of MI amounted to $0 \%$ (Table 1 ).

Immunohistochemical evaluation

\section{The p53 protein}

In the epithelial cell of the uterine endometrium of female rats treated with cladribine (A and B group), we observed the intensive expression of $\mathrm{p} 53$ protein in the cell nuclei and in the cytoplasm (Fig. 3). Moreover, a positive reaction was also visible in most of the cells of this epithelium. However, the intensity of the expression was varied, yet was considerably higher in the experimental groups than in the control group (Fig. 4). In addition, intensive expression of p53 protein in epithelial cells of the uterine glands was also observed.
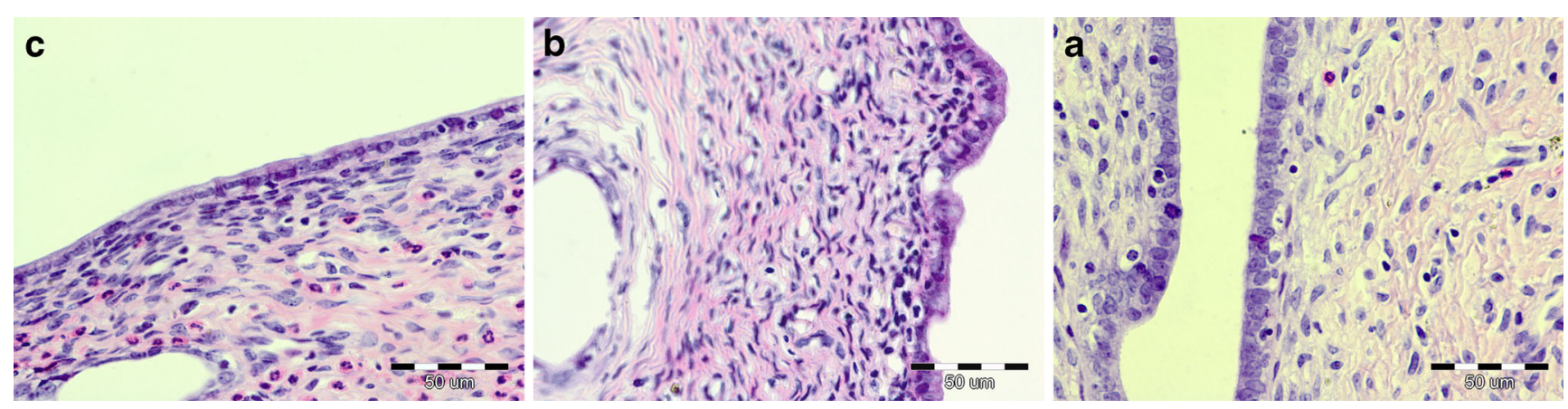

Fig. 1 Section of the uterine epithelium. $C$ control group, $A$ study group A, $B$ study group B; H\&E staining. Typical epithelium in the diestrus stage. No discernible pathological changes were observed 
Fig. 2 Section of the uterine epithelium. $C$ control group $(\times 1,000), B$ study group B $(\times 400)$, with mitotic figures (arrows). H\&E staining. A number mitotic figures were seen in groups $\mathrm{C}$ and $\mathrm{B}$ (median $=1.5 \%$ ); in group A, these were very rarely observed $($ median $=0)$
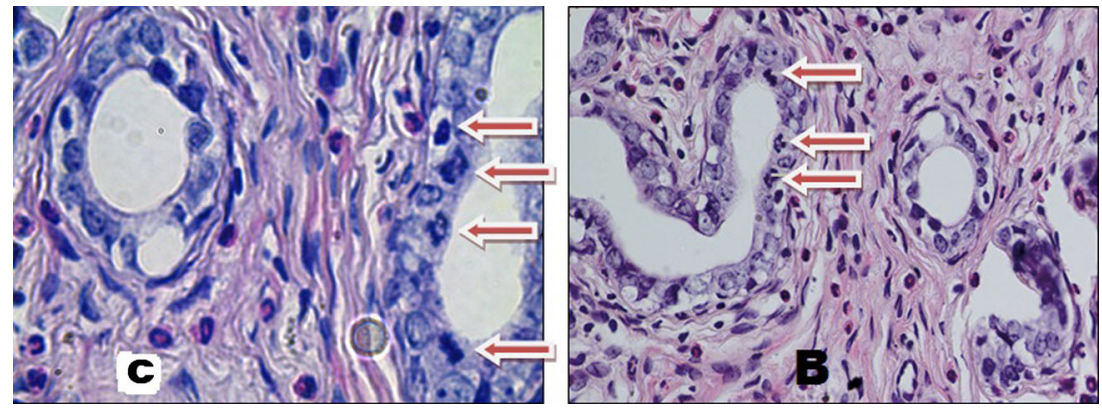

We also demonstrated a significant difference in the occurrence of positive expression of $\mathrm{p} 53$ protein between the experimental groups and the control group, as well as the lack of statistical difference in the expression of $\mathrm{p} 53$ protein occurrence between experimental groups A and B (Table 2). Furthermore, the intensity of the p53 protein expression was varied (Fig. 5): the strongest $(+++)$ was found in group A and the lowest in the control group (C).

\section{The Ki-67 antigen}

The expression of the Ki-67 antigen was also differentiated in its dependence in each research group (Fig. 6). In our study, we have shown a statistical difference in the occurrence of antigen Ki-67 immunoprecipitations between experimental and control groups, and between both experimental groups (Table 2).

The lowest expression of the nuclear antigen Ki-67 in the uterine epithelium was observed in experimental group A, and in only about one third of the cells were we able to perceive a positive immunohistochemical reaction (Fig. 4). In addition, the positive precipitations that were observed both in the epithelium covering the endometrium and in the epithelium of uterine glands showed a low intensity of expression and were assessed as $1(+)$ (Fig. 5). Moreover, in experimental group $\mathrm{B}$, we observed significantly more cells containing antigen Ki-67 positive immunoprecipitation, than in the uterine epithelium sourced from animals in experimental group A.

\section{Caspase 3}

In the epithelium of the organs harvested from female rats $24 \mathrm{~h}$ after exposure to cladribine (group A), caspase 3 expression was also considerably more intensive than in the epithelium of the uterus of animals decapitated 4 weeks later (group B), and in the control group (Fig. 7).

Furthermore, the greatest number of positive immunoprecipitations was observed in experimental group A ( $65 \%$ of the cells) and the least (35\%) in the control group (Fig. 4). The intensity of the caspase 3 expression in uterine epithelium of all groups was quite low (Fig. 5). We did not observe a high expression (a rating of $3[++]$ ) in any research group, while the expression evaluated as $2(++)$ appeared in only $4 \%$ of the cells of the material taken from group A, and $2 \%$ of uterine epithelial cells taken from group B, as well as $1 \%$ of the endometrial epithelial cells of the control group. A significant difference in the occurrence of positive caspase 3 expression was also observed between experimental groups and the control group, as well as between both experimental (A and B) groups (Table 2).

\section{Discussion}

The proper functioning of the organism is dependent on the presence of efficient mechanisms regulating the life processes of each cell within it, and undoubtedly, the $\mathrm{p} 53$ protein plays a primary role in regulating the multiple processes that occur even at the organ level. This protein protects against the reproduction of cells with the genome changes that result from DNA damage, by stopping the cell cycle and inducing the activation of cell repair mechanisms, as well as inducing cell death. Research data also points to its involvement in the inhibition of oncogenesis; hence, the gene TP53 is also called the suppressor gene (Sznarkowska et al. 2010). Moreover, the lack of active p 53 protein brings about roughly $50 \%$ of the mutation of the TP53 gene and is the basis of the origin of many cancers (Karagece Yalçin and Seçkın 2012). It is also
Table 1 Mitotic Index in uterine epithelium

\begin{tabular}{llll}
\hline Mitotic index in uterine epithelium & $\begin{array}{l}\text { Group A } \\
\text { MI }\end{array}$ & $\begin{array}{l}\text { Group B } \\
\text { MI }\end{array}$ & $\begin{array}{l}\text { Control group } \\
\text { MI }\end{array}$ \\
\hline Median & 0 & $1,5 \%$ & $1,5 \%$ \\
Mean \pm standard deviation (SD) & $0.5 \pm 0.849837 \%$ & $1.5 \pm 1.080123 \%$ & $1.6 \pm 0.966092 \%$ \\
\hline
\end{tabular}



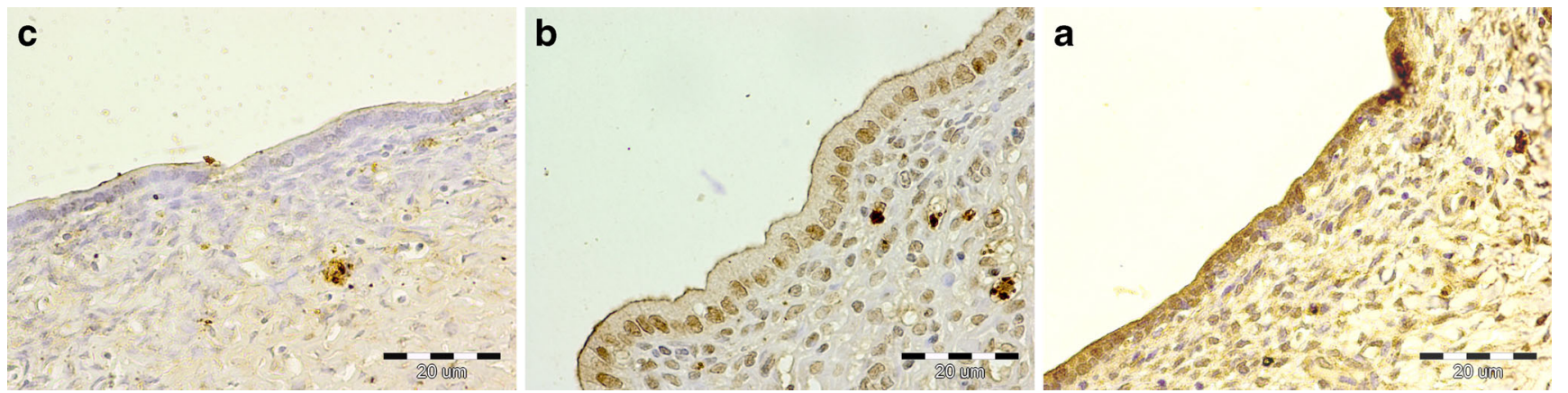

Fig. 3 Expression of 53 protein in uterine epithelial cells. $C$ control group, $A$ study group A, $B$ study group B. The higher expression is seen in groups A and $\mathrm{B}$

been documented that $\mathrm{p} 53$ protein is involved in the differentiation of stem cells, as well as in the reprogramming of somatic cells (Yi et al. 2012).

In our work, we investigated the expression of the p53 protein in uterine epithelium with active apoptosis (group A) and active proliferation (group B). Apoptosis was induced by the purine nucleoside analogue drug, cladribine. We compared the expression of $\mathrm{p} 53$ protein in tissues collected $24 \mathrm{~h}$ after last injection with cladribine (group A), in which the process of apoptosis was bolstered, with the expression in tissue taken 4 weeks after cessation of the cladribine supply, which showed active proliferation. By way of immunohistochemical tests, we assessed the expression of p53 protein, while also assessing the effector caspase 3 , by way of the molecular apoptosis marker and the nuclear antigen Ki-67, through the proliferation indicator (Chmielewski et al. 2008; Klöpfer et al. 2004; Sznarkowska et al. 2010; Gerdes et al. 1984). The research material was taken in the diestrus phase of estrus cycle, in which sex hormones do not have great involvement due to their low level (Marcondes et al. 2002).

Normally, the physiologically two-horned uterus of the female rat in the early phases of diestrus is not large and is scantily vascularized. Moreover, the uterus is slightly lined by low columnar epithelium containing single degenerating (apoptotic) cells. In the course of several hours, all the cells of the endometrium will have had surrendered to mitotic divisions. Following this, glands resume the secretion activity, and the epithelial cells of these glands intensely proliferate. Subsequently, gradual growth of the blood supply and the swelling of endometrium comes about (Westwood 2008).

In our work, the analyzed histomorphological view of the uterine epithelium of the examined animals showed this correct construction and sequencing. In addition, among the epithelial cells were many ciliated cells. Furthermore, the cytoplasm of these cells were weakly coloured with the acid stain (showing up as being brightly pink in colour), while the nuclei of the majority of cells were coloured with the basic stain (showing up as brightly navy blue coloured). Inside the nuclei, the nucleoli were evident. In the epithelium of the uterus we observed small cells undergoing mitotic divisions. This is typical for the epithelium of genital organs of the female rat in the diestrus phase (Sato et al. 1997; Westwood 2008). By comparing the histomorphological view of the uterine epithelium of the investigative groups of female rats, we observed a greater frequency of the occurrence of mitotic figures in experimental group B and in the control group (median of $\mathrm{IM}=1.5 \%$ ), than in experimental group A (median IM $=0 \%$ ).
Fig. 4 Percentage of positive expression in uterine epithelial cells. Positive expression of p53 protein and caspase 3 was observed more frequently in experimental groups $\mathrm{A}$ and $\mathrm{B}$ than in the control group. Positive expression of $\mathrm{Ki}-67$ antigen was rarely observed in group A

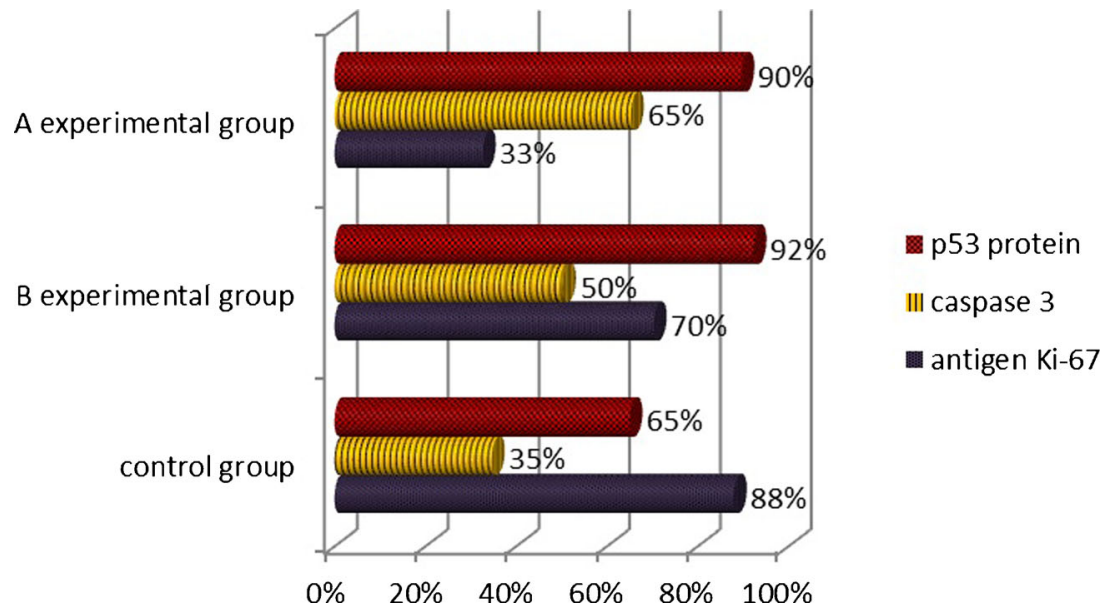


Table 2 The expression of proteins in the uterine epithelium depending on tested group

\begin{tabular}{llll}
\hline $\begin{array}{l}p \text { in Chi-square } \\
\text { test }\left(\chi^{2}\right)\end{array}$ & $\begin{array}{l}\text { Group A vs. } \\
\text { group B }\end{array}$ & $\begin{array}{l}\text { Group A vs. } \\
\text { control group (C) }\end{array}$ & $\begin{array}{l}\text { Group B vs. } \\
\text { control group (C) }\end{array}$ \\
\hline p53 protein & $p=0.2538$ & $p<0.0001$ & $p<0.0001$ \\
Caspase 3 & $p=0.0002$ & $p<0.0001$ & $p=0.0001$ \\
Antigen Ki-67 & $p<0.0001$ & $p<0.0001$ & $p<0.0001$ \\
\hline
\end{tabular}

For the confirmation of the cell proliferative activity, we undertook immunohistochemical tests of the nuclear Ki-67 antigen expression (which is acknowledged as the primary marker of cell proliferation (Gerdes et al. 1984)). This protein occurs in the cell nucleus, during cell division, and is present on the chromosomes. A positive expression of the $\mathrm{Ki}-67$ antigen in the cell occurs in phases of S, G2 and M of the cell cycle and in G1 following the mitotic division. The lack of expression of $\mathrm{Ki}-67$ antigen is observed only in rest cells in the G0 phase (Gerdes et al. 1984; Muskhelishvili et al. 2003). In our study, the expression of nuclear Ki-67 antigen was the lowest among the uterine epithelial cells of animals of experimental group A (positive in $33 \%$ of the cells), whereas in the epithelium of animals in experimental group B, expression of the antigen was higher (and positive in about $70 \%$ of the uterine epithelial cells). In regard to the uterine epithelium of the animals of the control group, this showed far beyond that found in groups $\mathrm{A}$ and $\mathrm{B}$, a positive expression of the $\mathrm{Ki}-67$ antigen ( $88 \%$ of the epithelial cells of the uterus). The presence of differences in the expression of this proliferation marker - as revealed through the immunohistochemical method in the individual research groups - confirmed the results of the $\mathrm{MI}$ analysis in the $\mathrm{H} \& \mathrm{E}$ staining. A positive expression of this antigen was observed in the considerably greater percentage of cells than that during IM. This is connected with the presence of this antigen not only during mitotic division, but also in other active phases of the cell cycle. Hence, it is possible to score a greater number of cells by the use of immunohistochemical tests (Gerdes et al. 1984).

For the purpose of ascertaining the qualifications of the quantity of apoptotic cells found in the epithelium of the examined organs, we undertook an investigation of the caspase 3 expression by the immunohistochemical method. Caspase 3 is one of the more important executive caspases in the apoptosis process, as it is directly involved in the break-up of intracellular structures that lead to the formation of apoptotic bodies. Thus, a measurement of its activity is used to evaluate the intensification of this process in the cells (Chmielewski et al. 2008). The p53 protein also plays a crucial role in the process of cladribine-induced apoptosis, which was confirmed by several studies (Klöpfer et al. 2004; Sznarkowska et al. 2010; Jędrych et al. 2013; WawrykGawda et al. 2011). In our study, we observed a high expression of p53 protein in experimental group A. In the tissue of

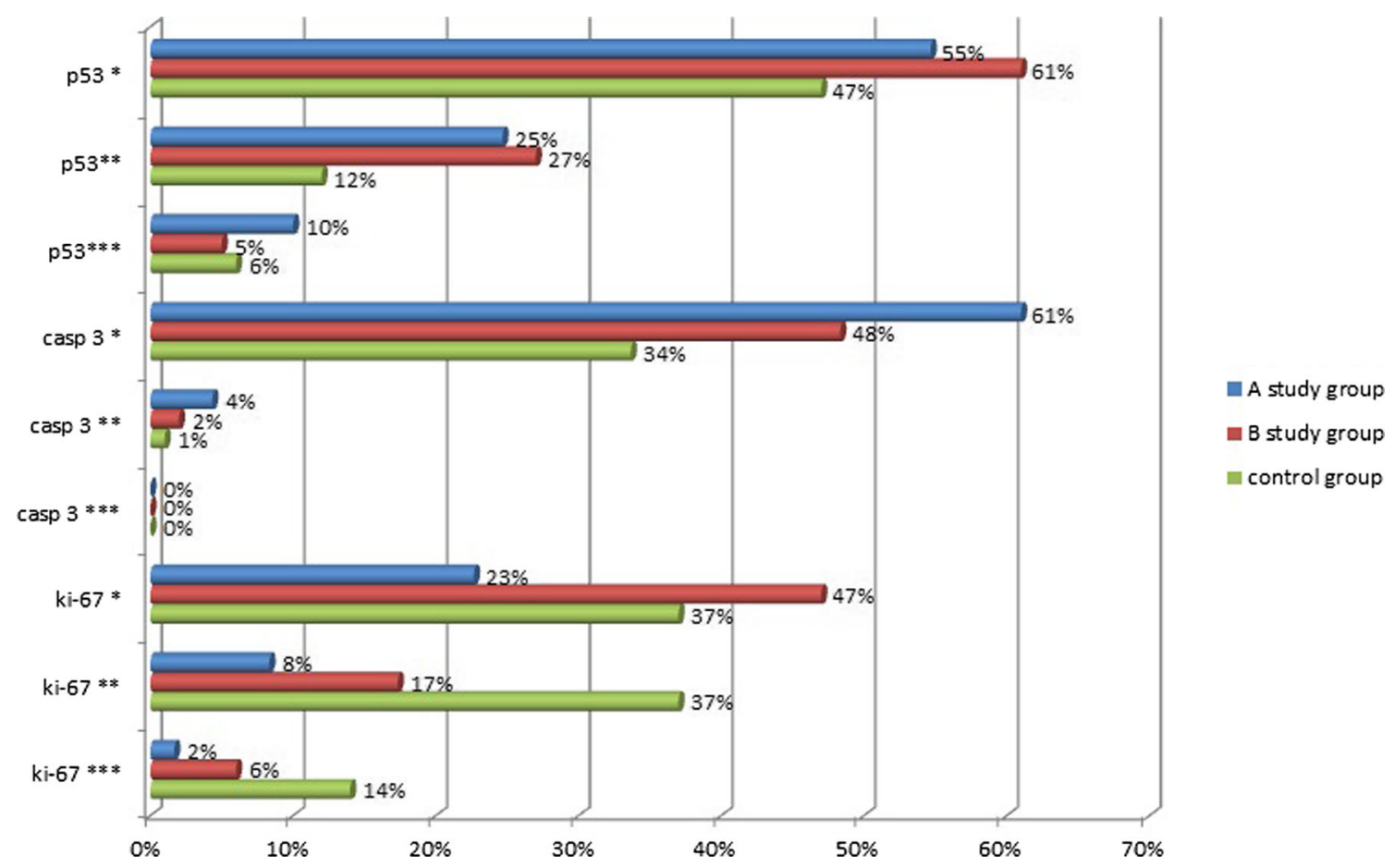

Fig. 5 The expression of p53 protein, antigen Ki-67 and caspase 3 of defined intensity in particular research groups. The higher expression of p53 protein was seen in groups A and B. The expression of caspase 3 was

highest in group $\mathrm{A}$, lower in group $\mathrm{B}$, and lowest in the control group. The expression of antigen $\mathrm{Ki}-67$ was lowest in group $\mathrm{A}$, and higher in group $\mathrm{B}$ and the control group 

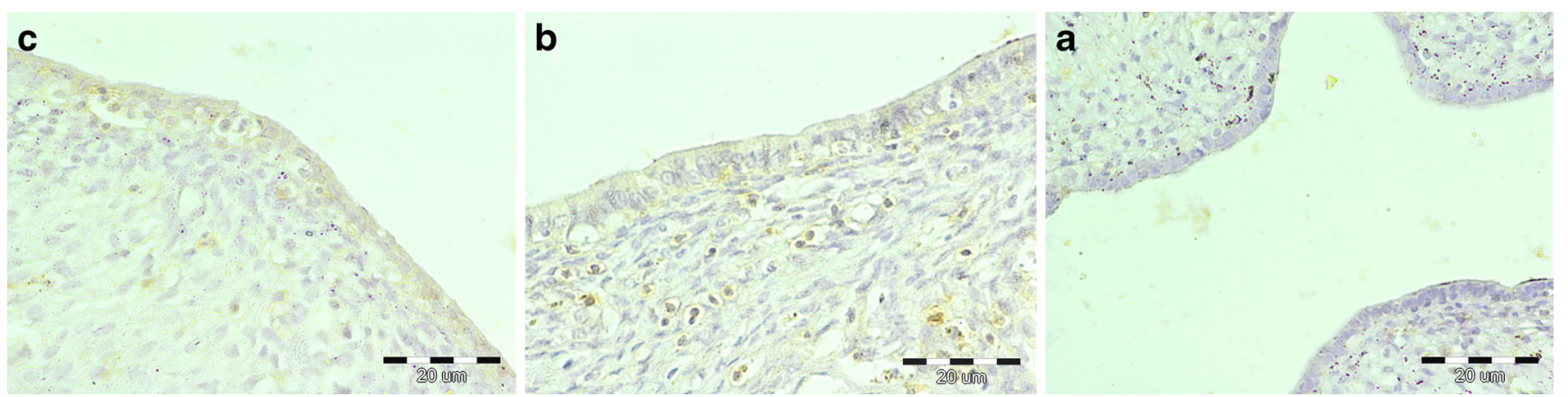

Fig. 6 Expression of antigen Ki-67 in uterus epithelial cells. $C$ control group, $A$ study group A, $B$ study group B. The higher expression was found in group B and the control group

this group, as much as $90 \%$ of the cells showed a positive expression (Fig. 4). Moreover, a high reaction, assessed as 3 $(+++)$, were observed in $10 \%$ of the epithelial cells of the endometrium (Fig. 5), while $25 \%$ of the epithelial cells lining the cavity of the uterus expression were evaluated as $2(++)$. In addition, in the epithelial cell of the uterine endometrium of female rats decapitated 4 weeks after the end of chemotherapy we observed the intense reaction of the $\mathrm{p} 53$ protein. In this group, a positive response directed against the $\mathrm{p} 53$ protein was found within about $92 \%$ of the epithelial cells of the endometrium. Furthermore, a high response $(+++)$ was observed in approximately $5 \%$ of the epithelial cells of the uterus. However, statistical analysis of the obtained results showed that the difference in the expression of $\mathrm{p} 53$ protein intensity in the cells of the epithelium after 4 weeks from the last dose of cladribine in respect to group B (decapitated $24 \mathrm{~h}$ after the last 2 -CdA application) was not statistically significant $(p>0.05$, Table 2). Moreover, the intensity of this protein expression was significantly lower in the epithelium of the control group $(p<0.0001)$.

To interpret the obtained results, we should note the evidence of $\mathrm{p} 53$ protein precipitations in the cellular nuclei cell results from the presence of the active form of this protein. In cells not subjected to any stress, p53 protein is inactive and its positive expression as detected by immunohistochemical methods, physiologically can occur only in the cytoplasm. However, the presence of nuclear p53 protein expression indicates need for the mobilization of the intracellular repair processes dependent on the $\mathrm{p} 53$ protein (Sznarkowska et al. 2010; Liu and Kulecz-Martin 2001). Furthermore, an increase in the intensity of expression of this protein is associated with its enhanced concentration in the cell, which in turn is associated with greater damage occurring in the cell. According to Sznarkowska et al. (2010), arrest of the cell cycle and the DNA damage repair require less active p53 protein concentration, while apoptotic induction is necessary for it to have a greater level in the cell.

From our data (discussed above) and observations, it can be concluded that the enhanced intensity of growth protein p53 expression in the epithelium of animals in the experimental groups can be triggered by actions resulting from cladribine DNA damage. This is in concordance with previous research in that a similar increase in the expression of $\mathrm{p} 53$ protein was observed in several studies of the lymphoid cells treated with cladribine (De Viron et al. 2009; Johnston 2011; Nocentini 1996). In addition, the presence of active forms of the protein p53 and caspase 3 in the cell at the same time is due to the existence of certain changes with which cells can no longer function properly. Such cells are then eliminated from the body by way of programmed death (Korzeniewska-Dyl 2007; Sznarkowska et al. 2010).

In our research, the most intense caspase 3 expression within the sampled uterine epithelial cells was in experimental group A. In these tissues, $65 \%$ of uterine epithelial cells showed a positive expression of caspase 3, while in experimental group B, positive precipitations were observed in $50 \%$

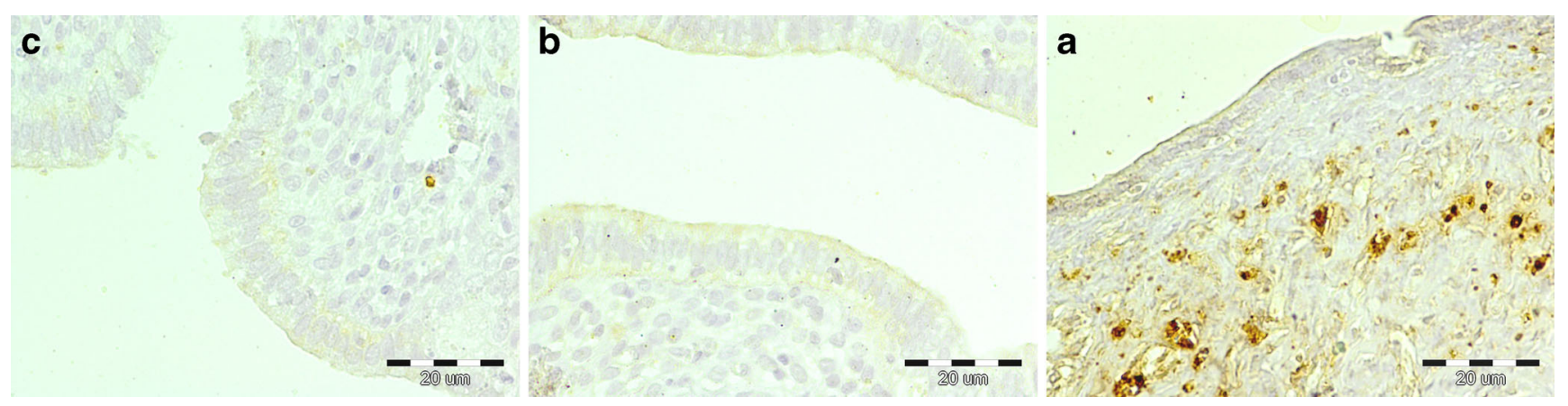

Fig. 7 Expression of caspase 3 in uterus epithelial cells. $C$ control group, $A$ study group A, $B$ study group B 
of epithelial cells of the uterus (Fig. 4). Coefficients of significant dependence among caspase 3 expression in these groups, in all of the tests, were statistically significant $(p<0.05)$. These results were the same between the experimental groups and the control group (Table 2). In the control group, the positive immunohistochemical reaction of caspase 3 was observed in $35 \%$ of the epithelial cells of the uterus.

The positive precipitations observed in epithelium of animals receiving only saline injections indicate the presence of single apoptotic cells in these organs, which is physiologically normal during this estrous cycle phase in female rats (Sato et al. 1997; Westwood 2008). However, the more intensive reactions both $\mathrm{p} 53$ proteins and caspase 3 in the epithelium of group B rats, as compared with the control group, according to previously described data, may indicate that, in parts of the cells of the epithelium, the changes in the genetic material induced by cladribine were so significant that the ongoing repair mechanisms in these cells had been overwhelmed. They are therefore directed towards the programmatic death pathway with the assistance of the $\mathrm{p} 53$ protein.

When considering the reasons for the strong expression of p53 protein in the cells of the epithelium, one should keep in mind the other processes regulated by this protein. In addition to the described damage of the genome, the directly activated p53protein observed in groups receiving cladribine may also lead to the intensification of the regenerative processes (Sznarkowska et al. 2010). Hence, an increase in the intracellular activity of $\mathrm{p} 53$ protein in group B may therefore be associated with the higher proliferation process of this epithelium (Borner et al. 1997; Mendoza-Rodríguez et al. 2002). This, again, is in line with previous studies. In Borner et al.'s (1997) study, a growth of $\mathrm{p} 53$ protein activity was observed in both human peripheral blood mononuclear cells (PBMC), which were treated with cladribine (which showed similar characteristics within the apoptotic cells), and in cells induced to proliferate through the mitogen phytohemagglutinin (PHA). However, in a study of Mendoza-Rodriguez et al., the increased expression of both p 53 mRNA and p53 proteins within the epithelial cells of the endometrium at the metestrus phase was associated with increased proliferation activity of these cells. Furthermore, Mendoza-Rodríguez et al. (2002) found that, while in the estrus phase (when the number of apoptotic cells increases), this expression was at the lowest level.

To summarize, in our study, the stronger $\mathrm{p} 53$ protein expression in the epithelial cells of experimental group $\mathrm{A}$, and at the same time, the lowest expression of nuclear antigen Ki-67 observed in this group was associated with the active process of apoptosis and inhibition of proliferation. Four weeks after the last dose of cladribine (group B), the stronger expression of p53 protein (compared with the control group) is likely associated with the existing changes in the cell's genome, the effects of the ongoing repair mechanisms, as well as the greater proliferation activity (as compared to experimental group A), as evidenced by the stronger expression of the Ki67 nuclear antigen in this group.

\section{Conclusions}

The $\mathrm{p} 53$ protein takes an active part in the process of apoptosis that is induced by cladribine and by cellular proliferation, and this leads to organ regeneration.

Conflict of interest The authors declare that they have no conflict of interest.

Open Access This article is distributed under the terms of the Creative Commons Attribution License which permits any use, distribution, and reproduction in any medium, provided the original author(s) and the source are credited.

\section{References}

Borner MM, Joncourt F, Hotz MA (1997) Type of inducing signal regulates transactivation by p53. Biochim Biophys Acta 1358(3): 314-320

Chmielewski M, Linke K, Zabel M (2008) Metody wykrywania zjawiska apoptozy w komórkach wątrobowych in situ. [Methods of detecting the phenomenon of apoptosis in liver cells in situ.] (in Polish). Nowiny Lekarskie 77(3):223-226

De Viron E, Knoops L, Connerotte T, Smal C, Michaux L, Saussoy P, Vannuffel P, Beert E, Vekemans MC, Hermans C, Bontemps F, Van Den Neste E (2009) Impaired up-regulation of polo-like kinase 2 in B-cell chronic lymphocytic leukaemia lymphocytes resistant to fludarabine and 2-chlorodeoxyadenosine: a potential marker of defective damage response. Br J Haematol 147(5):641-652. doi:10. $1111 / j .1365-2141.2009 .07900 . x$

Di Giovanni S, Rathore K (2012) P53-Dependent pathways in neurite outgrowth and axonal regeneration. Cell Tissue Res 349(1):87-95. doi:10.1007/s00441-011-1292-5

Gerdes J, Lemke H, Baisch H, Wacker HH, Schwab U, Stein H (1984) Cell cycle analysis of a cell proliferation-associated human nuclear antigen defined by the monoclonal antibody Ki-67. J Immunol 133(4):1710-1715

Jędrych M, Wawryk-Gawda E, Jodłowska-Jędrych B, Chylińska-Wrzos P, Jasiński L (2013) Immunohistochemical evaluation of cell proliferation and apoptosis marker in ovarian surface epithelial cells of cladribine-treated rats. Protoplasma. doi:10.1007/s00709-012-0461-z

Johnston JB (2011) Mechanism of action of pentostatin and cladribine in hairy cell leukemia. Leuk Lymphoma 52(Suppl 2):43-45. doi:10. 3109/10428194.2011.570394

Karagece Yalçin U, Seçkın S (2012) The expression of p53 and COX-2 in basal cell carcinoma, squamous cell carcinoma and actinic keratosis cases. Turk Patoloji Derg 28(2):119-127. doi:10.5146/tjpath.2012. 01110

Klöpfer A, Hasenjäger A, Belka C, Schulze-Osthoff K, Dörken B, Daniel PT (2004) Adenine deoxynucleotides fludarabine and cladribine induce apoptosis in a CD95/Fas receptor, FADD and caspase-8independent manner by activation of the mitochondrial cell death pathway. Oncogene 23(58):9408-9418. doi:10.1038/sj.onc. 1207975 
Korzeniewska-Dyl I (2007) Kaspazy — struktura i funkcja. [Caspases structure and function.]. Pol Merkur Lekarski 23(138):403-407

Laptenko O, Prives C (2006) Transcriptional regulation by $\mathrm{p} 53$ : one protein, many possibilities. Cell Death Differ 13(6):951-961

Liu Y, Kulecz-Martin M (2001) P53 protein at the hub of cellular DNA damage response pathway through sequence-specific and nonsequence-specific DNA binding. Carcinogenesis 22(6):851-860

Marcondes FK, Bianchi FJ, Tanno AP (2002) Determination of the estrous cycle phases of rats: some helpful considerations. Braz J Biol 62(4A):609-614

Mendoza-Rodríguez CA, Merchant-Larios H, Segura-Valdez Md Mde L, Moreno-Mendoza N, Cruz ME, Arteaga-López P, Camacho-Arroyo I, Dominguez R, Cerbón M (2002) Expression of p53 in luminal and glandular epithelium during the growth and regression of rat uterus during the estrous cycle. Mol Reprod Dev 61(4):445-452

Muskhelishvili L, Latendresse JR, Kodell RL, Henderson EB (2003) Evaluation of cell proliferation in rat tissues with BrdU, PCNA, Ki-67(MIB-5) immunohistochemistry and in situ hybridization for histone mRNA. J Histochem Cytochem 51(12):1681-1688

Nocentini G (1996) Ribonucleotide reductase inhibitors: new strategies for cancer chemotherapy. Crit Rev Oncol Hematol 22(2):89-126

Pekova S, Mazal O, Cmejla R, Hardekopf DW, Plachy R, Zejskova L, Haugvicova R, Jancuskova T, Karas M, Koza V, Smolej L, Bezdickova L, Kozak T (2011) A comprehensive study of TP53 mutations in chronic lymphocytic leukemia: analysis of 1287 diagnostic and 1148 follow-up CLL samples. Leuk Res 35(7):889-898. doi:10.1016/j.leukres.2010.12.016

Sato T, Fukazawa Y, Kojima H, Enari M, Iguchi T, Ohta Y (1997) Apoptotic cell death during the estrous cycle in the rat uterus and vagina. Anat Rec 248(1):76-83

Sznarkowska A, Olszewski R, Zawacka-Pankau J (2010) Farmakologiczna aktywacja supresora nowotworu, natywnego białka p53 jako obiecująca strategia zwalczania nowotworów. [Pharmacological activation of tumor suppressor, wild-type p53 as a promising strategy to fight cancer.] (in Polish). Postepy Hig Med Dośw (online) 64:396407

Takimoto R, El-Deiry WS (2000) Wild-type p53 transactivates the KILLER/DR5 gene through an intronic sequence-specific DNAbinding site. Oncogene 19(14):1735-1743

Wawryk-Gawda E, Chylińska-Wrzos P, Jodłowska-Jędrych B, LisSochocka M (2011) Use of selected purine analogs in neoplastic and autoimmune diseases. Ann UMCS Sect DDD 24(4):29-47

Westwood FR (2008) The female rat reproductive cycle: a practical histological guide to staging. Toxicol Pathol 36:375-384. doi:10. 1177/0192623308315665

Yi L, Lu C, Hu W, Sun Y, Levine AJ (2012) Multiple roles of p53-related pathways in somatic cell reprogramming and stem cell differentiation. Cancer Res 72(21):5635-5645. doi:10.1158/0008-5472.CAN-12-1451 